\title{
Determination of microbiological and sensory parameters of fish fillets with propolis preserved under refrigeration
}

\section{Determinación de parámetros microbiológico y sensorial de filetes de pescado preservados con propóleos bajo refrigeración}

\author{
Héctor Suarez M, ${ }^{1 *}$ Ph.D, Álvaro Jiménez T, ${ }^{2}$ M.Sc, Consuelo Díaz M, ${ }^{1}$ Ph.D.
}

Universidad Nacional de Colombia. ${ }^{1}$ Instituto de Ciencia y Tecnología de Alimentos-ICTA. ${ }^{2}$ Postgrado en Ciencia y Tecnología de Alimentos, Carrera 30 N 45-03 Edificio 500 C. Cundinamarca, Bogotá. *Correspondencia: hsuarezm@unal.edu.co

Received: July 2013; Accepted: November 2013.

\begin{abstract}
Objective: To determine the ability of propolis preservative cachama fillets during refrigerated storage. Materials and method. Ethanol extracts of propolis (EEP) were used in cachama fillets. The treatments included: i) $96 \%$ ethanol alcohol as the control; ii) $0.8 \%$ EEP; iii) $1.2 \%$ EEP; and iv) liquid smoke. A in vitro analysis was used to determine the inhibitory effect of propolis on Staphylococcus aureus, Escherichia coli, Salmonella sp. and Clostridium sp. and on the fish matrix to determine the mesophiles, psychrotrophiles, total coliforms, fecal coliforms, sulphite reducing spores and the presence of Salmonella. Results. The results of the in vitro analysis demonstrated the control that the EEP had over the evaluated microorganisms without presenting significant differences between the different concentrations $(p>0.05)$. The analyses of the fish fillet matrix presented acceptable contents for the evaluated microorganisms in the treatments with EEP. A different situation was seen in the treatment with liquid smoke and the control, which had samples that where rejected after 20 days of storage. The sensory analysis showed acceptance for the samples with EEP until the end of the storage period but low marks for the treatment with liquid smoke and the control. Conclusions. The EEP used in this study could be effective for the control of Gram positive bacteria and some Gram negative bacteria that are present in cachama fillets; and could be an alternative to the use of chemical preservatives.
\end{abstract}

Key words: Cachama, ethanol extracts, microorganisms, preservation, Piaractus braquipomus (Sources: UNESCO, FAO).

\section{RESUMEN}

Objetivo. Determinar la capacidad conservante de propóleos en filetes de cachama durante el almacenamiento bajo refrigeración. Materiales y método. Se utilizaron extractos etanólicos de propóleos (EEP) en filetes del pez cachama (Piaractus brachypomus). Los tratamientos realizados fueron: i) alcohol etanólico $96 \% \mathrm{v} / \mathrm{v}$ como control; ii) EEP $0.8 \%$; iii) EEP $1.2 \%$ y iv) Humo líquido. Fueron realizados análisis in vitro para determinar la actividad inhibitoria de los propóleos frente a Staphylococcus aureus, Escherichia coli, Salmonella spp., y Clostridium sp., y en la matriz de pescado para determinar la presencia de mesófilos, psicrotrófilos, coliformes totales, coliformes fecales, esporas sulfitoreductoras 
y de Salmonella spp. Resultados. Los resultados de los análisis in vitro mostraron control de los EEP sobre los microorganismos utilizados sin presentar diferencias significativas ( $p>0.05)$. Los análisis en la matriz del filete de pescado presentaron conteos aceptables para los microorganismos evaluados en los tratamientos con EEP. Situación diferente para los tratamientos con el humo líquido y el control, siendo las muestras rechazadas a partir del día 20 de almacenamiento. El análisis sensorial mostró aceptación de las muestras con EEP hasta el final del período de almacenamiento y bajas puntuaciones para los tratamientos con el humo líquido y el control. Conclusiones. Los EEP utilizados podrían ser efectivos en el control de bacterias Gram positivas y algunas Gram negativas presentes en filetes de cachama y serian una opción para evitar el uso de conservantes químicos.

Palabras clave: Cachama, conservación, extractos etanólicos, microorganismos, Piaractus brachypomus (Fuentes: UNESCO, FAO).

\section{INTRODUCTION}

The cachama fish (Piaractus brachypomus) hails from different basins of South America. In Colombia is the main native species in aquaculture. On the other hand, propolis is a natural, resinous substance and a strong adhesive, which is collected by Africanized honeybees (Apis mellifera L.) from leaf buds of trees and plants, and mixed with pollen and enzymes that are secreted by the bees (1). The bees use propolis as a sealant for the interior walls of hives and as a protective barrier against intruders (2). In general, propolis is composed of balsam and vegetative resin $(50 \% \mathrm{v} / \mathrm{v})$, wax $(30 \% \mathrm{v} / \mathrm{v})$, essential herb oils $(10 \% \mathrm{v} / \mathrm{v})$, pollen ( $5 \% \mathrm{v} / \mathrm{v})$ and other substances ( $5 \% \mathrm{v} / \mathrm{v})$, including organic remains (2). In ethanol extraction, the wax and organic residues are removed during the process. The ethanol extract that is obtained has more than 300 bioactive compounds, such as polyphenols, terpenoids, steroids, sugars and amino acids that have been detected in raw propolis.

Propolis is considered responsible for the lower incidence of bacteria and fungi in hives. The action against microorganisms is an essential characteristic of propolis. Furthermore, humans have used propolis for centuries due to the pharmaceutical properties (1). The antimicrobial biological activity is due to the presence of flavonoid and phenol compounds, although the exact action of this mechanism is unknown (3). The antimicrobial effect of propolis depends on the propolis extract concentration and is influenced by the extraction method (4). In addition, studies have shown that allergic reactions are not slightly common and that propolis is relatively no toxic, with effect values not observed (NOEL) in $1400 \mathrm{mg} / \mathrm{kg}$ of body weight/day in mice (2).

A number of studies have mainly described the antimicrobial action against microorganisms $(5,6)$. The antibacterial effect of propolis

\section{INTRODUCCIÓN}

La cachama (Piaractus brachypomus) viene de diferentes cuencas de Sudamérica. En Colombia es la principal especie nativa en acuacultura. Por otro lado, propóleos es una sustancia natural, resinosa y fuertemente adhesiva, que es recolectada por abejas melíferas africanizadas (Apis mellifera $L$.) de las yemas y hojas de árboles y plantas, mezclada con polen y enzimas que las abejas secretan (1). Las abejas usan propóleos para sellar las paredes interiores de sus colmenas y como una barrera protectora contra intrusos (2). En general, los propóleos son compuestos de bálsamo y resina vegetal $(50 \% \mathrm{v} / \mathrm{v})$, cera $(30 \% \mathrm{v} / \mathrm{v})$, aceites esenciales de hierbas $(10 \% \mathrm{v} / \mathrm{v})$, polen $(5 \% \mathrm{v} / \mathrm{v})$ y otras sustancias $(5 \% \mathrm{v} / \mathrm{v})$, incluyendo restos orgánicos (2). En la extracción etanólica, los residuos orgánicos y de la cera son removidos durante el proceso. El extracto etanólico que se obtiene contiene más de 300 compuestos bioactivos, tales como polifenoles, terpenoides, esteroides, azucares y aminoácidos que han sido detectados en propóleos crudo.

Los propóleos son considerados responsables de la baja incidencia de bacterias y hongos en las colmenas. Esta acción contra los microrganismos es una característica esencial de los propóleos. Además, los humanos han usado propóleos por siglos por sus propiedades farmacéuticas (1). La actividad biológica antimicrobiano es debido a la presencia de compuestos de flavonoides y fenol, aunque la acción exacta de este mecanismo no se conoce (3). El efecto antimicrobiano de los propóleos depende de la concentración del extracto de propóleos y es afectado por el método de extracción (4). Además, estudios han mostrado que las reacciones alérgicas no son comunes y que los propóleos son relativamente no toxico, con valores de efecto no observados (NOEL) en $1400 \mathrm{mg} / \mathrm{kg}$ de peso corporal/día en ratones (2).

Numerosos estudios han descrito principalmente la acción antimicrobiana contra los microorganismos $(5,6)$. El efecto antibacteriano de propóleos 
on pathogens transmitted by food, such as Bacilluscereus, Staphylococcus aureus, Listeria monocytogenes, Enterococcus faecalis and Perfringenes Clostridium, has shown a potential for preserving food against such pathogens $(7,8)$. In addition, propolis contains actions that not only counteract bacteria and fungi but also viruses. Drago and De Vecchi (5) reported that propolis is capable is inhibiting the growth of influenza viruses, adenoviruses, parainfluenza viruses, and the Herpes simplextype-1 virus.

In food applications, propolis has been proposed as a preservative for meat products due to the antimicrobial effect (9) and as a bactericide and insecticide in food packaging (10). Furthermore, it has been reported that the addition of propolis doubles or triples the shelf-life of frozen fish (8). In addition, the liquid smoke has antimicrobial activity, but must be used under certain thermal conditions.

In considering safety factors, it has been reported that various propolis compounds are present in nutritional and/or food additives and are considered GRAS (Generally recognize as safe) (2). These characteristics make propolis an attractive candidate for natural preservation in new food applications and able to satisfy the demand for antioxidants and antimicrobials that comes from the growing awareness of consumers for natural food and the omission of processing and chemical preservatives $(9,11)$. This study aimed to evaluate the antimicrobial and sensory capabilities of ethanol extracts of propolis applied to cachama fillets during a period of refrigerated storage.

\section{MATERIALS AND METHODS}

Ethanol extract of propolis (EEP). Propolis from the Villa de Leiva, Boyacá (Colombia) was utilized in this study. Twenty five $\%(\mathrm{v} / \mathrm{v})$ ethanol extract of propolis in $96 \%(\mathrm{v} / \mathrm{v})$ ethanol was used. Hundrey $\mathrm{g}$ of propolis were introduced in a precipitated glass, then $400 \mathrm{ml}$ of ethanol $96 \%(\mathrm{v} / \mathrm{v})$ were added. The mixture was shaken during two hours, and it was left at rest overnight, and then it was filtered. The residue was subjected to a secondary extraction with the same proportions as the first one. Finally the two extracts were mixed and frozen to precipitate other compounds. The supernatant EEP was used for the tests and its solid concentration of $8 \%(\mathrm{v} / \mathrm{v})$ was established for the oven-drying method.

Preparation of the fillets. Transversal cuts were used on the cachama fillets to cut en patógenos transmitidos por alimentos, tales como Bacilluscereus, Staphylococcus aureus, Listeria monocytogenes, Enterococcus faecalis y Perfringenes Clostridium, han mostrado ser un potencial para preservar alimentos contra tales patógenos $(7,8)$. Adicionalmente, los propóleos contiene actividad que no solo contrarrestan bacteria y hongos pero también los virus. Drago y De Vecchi (5) reportaron que los propóleos son capaces de inhibir el crecimiento de los virus de influenza, adenovirus, para influenza, y el virus Herpes simplex tipo-1.

En alimentos los propóleos han sido recomendados como conservantes para productos cárnicos debido a su efecto antimicrobiano (9) y como bactericida e insecticida en empaques de alimentos (10). Además, se ha reportado que añadir propóleos extiende de dos a tres veces la vida útil de pescado congelado (8). Adicionalmente el humo líquido tiene actividad antimicrobiano, pero debe ser usado bajo condiciones térmicas.

Al considerar factores de seguridad se ha reportado que varios compuestos de los propóleos están presente en aditivos nutricionales y/o alimentos y son considerados GRAS (generalmente reconocidos como seguros) (2). Estas características hacen de los propóleos un candidato atractivo para la conservación natural en aplicaciones alimenticias nuevas y para poder satisfacer la demanda de antioxidantes y antimicrobianos, que nace de una conciencia creciente de consumidores de alimentos naturales y la omisión de procesamientos y conservantes químicos $(9,11)$. El objetivo de este estudio fue evaluar las capacidades antimicrobianas y sensoriales de los extractos etanólicos de los propóleos aplicados a filetes de cachama durante un periodo de almacenaje refrigerado.

\section{MATERIALES Y MÉTODOS}

Extracto de etanólico de propóleos (EEP). Se utilizaron propóleos de Villa de Leiva, Boyacá (Colombia) en este estudio. Veinte cinco \% (v/v) de extracto etanólicos de propóleos en $96 \% \mathrm{v} / \mathrm{v}$ ) de etanol se usaron. Cien gramos de propóleos se introdujeron en un vidrio precipitado, y después se añadieron $400 \mathrm{ml}$ de etanol $96 \%$ (v/v). La mezcla se agitó por dos horas y se dejó reposar durante la noche, y después se filtró. Los residuos fueron sujetos a una extracción secundaria con las mismas proporciones de la primera. Finalmente los dos extractos se mezclaron y se congelaron para precipitar otros compuestos. El sobrenadante de EEP se usó para estos ensayos y su concentración solida de $8 \%(\mathrm{v} / \mathrm{v})$ fue establecido para el método de secado al horno. 
intramuscular bones. The following treatments were used: i) Control, $96 \%$ (v/v) ethanol alcohol; ii) propolis at a concentration of $0.8 \mathrm{mg} /$ $\mathrm{ml}$; iii) propolis at a concentration of $1.2 \mathrm{mg} /$ $\mathrm{ml}$; iv) liquid smoke. The fillets were packed in vacuum sealed bags and stored at $3^{\circ} \mathrm{C}$ for 24 days.

Microbiological Analysis. The following microbiological analyses were carried out:

In vitro tests. Staphylococcus aureus, Escherichia coli, Salmonella sp. and Clostridium sp., strains were obtained from the Microbiology Laboratory at the Instituto de Ciencia y Tecnología de Alimentos - ICTA at the Universidad Nacional de Colombia, Bogotá. For the activation of Clostridium sp., BHI broth (Oxoid) was used; for Salmonella sp., a nutritive broth (Oxoid) according to ATCC 13076; and for Staphylococcus aureus, Escherichia coli, TSB broth (Merck) according to ATCC 25923 and ATCC 25922, respectively. The strains were incubated overnight after 18 hours of growth.

For the analysis of the inhibitory activity of propolis, a diffusion test was carried out in Mueller-Hinton agar. One $\mathrm{ml}$ of each strain was grown using 0.5 in the MacFarland scale, corresponding to a concentration of $1.5 \times 10^{9}$ cells on the surface. Six mm diameter of filter paper discs were impregnated with three different propolis concentrations $(0.8,1.2$ and $1.6 \mathrm{mg} / \mathrm{mL}$ ) and a control with $96 \%(\mathrm{v} / \mathrm{v})$ ethanol alcohol was used. They were incubated for 48 hours and the inhibition halos were measured.

It was found that the three concentrations inhibited the growth of the utilized pathogens and that there were no significant differences for the inhibitory effect, so the two lower concentrations were selected $(0.8$ and $1.2 \mathrm{mg} /$ $\mathrm{mL})$.

Cachama fillet tests. The plate mesophile (heterotrophs), psychrotrophile, total coliform, fecal coliform, and sulphite reducing spore counts and the presence of Salmonella spp., were determined according to the standards of the Normas del Instituto Nacional de Vigilancia de Medicamentos y Alimentos- INVIMA and Normas Técnicas Colombianas (12).

Plate mesophile and psychrotrophile count: $11 \mathrm{~g}$ of the sample were added to $99 \mathrm{ml}$ of peptonated water $(0.1 \% \mathrm{w} / \mathrm{v})$ and placed in petri dishes with PlateCount Agar and incubated at $35 \pm 2{ }^{\circ} \mathrm{C}$ for 48 hours. For psychrotrophiles, they were incubated at $4 \pm 0.5^{\circ} \mathrm{C}$ for $5-7$ days. The results
Preparación de los filetes. Se hicieron cortes transversales en los filetes de cachama para cortar las espinas intramusculares. Fueron utilizados los siguientes tratamientos: i) Control, 96\% (v/v) alcohol etanol; ii) propóleos a una concentración de $0.8 \mathrm{mg} / \mathrm{ml}$; iii) propóleos a una concentración de $1.2 \mathrm{mg} / \mathrm{ml}$; iv) humo líquido. Los filetes fueron empacados en bolsas selladas al vacío y almacenadas a $3^{\circ} \mathrm{C}$ por 24 días.

Análisis microbiológico. Los siguientes análisis microbiológicos se llevaron a cabo:

Ensayos in vitro. Cepas de Staphylococcus aureus, Escherichia coli, Salmonella sp. y Clostridium sp., se obtuvieron del laboratorio de microbiología del Instituto de Ciencia y Tecnología de Alimentos - ICTA de la Universidad Nacional de Colombia, Bogotá. Para activar Clostridium sp., se usó caldo BHI (Oxoid); para Salmonella sp., un caldo nutritivo (Oxoid) según ATCC 13076; y para Staphylococcus aureus, Escherichia coli, caldo TSB (Merck) según ATCC 25923 y ATCC 25922, respectivamente. Las cepas fueron incubadas durante la noche para obtener 18 horas de crecimiento.

Para el análisis de la actividad inhibidora de propóleos, un ensayo de difusión se llevó a cabo en agar MuellerHinton. Un $\mathrm{ml}$ de cada cepa se cultivó utilizando 0.5 en la escala MacFarland, correspondiendo a una concentración de $1.5 \times 10^{9}$ células en la superficie. Discos de papel de filtro de seis $\mathrm{mm}$ de diámetro fueron impregnados con tres diferentes concentraciones de propóleos $(0.8,1.2$ y $1.6 \mathrm{mg} / \mathrm{mL})$ y un control con $96 \%(\mathrm{v} / \mathrm{v})$ alcohol etanol se usó. Fueron incubados por 48 horas y se midieron los halos de inhibición.

Se encontró que las tres concentraciones inhibieron el crecimiento de los patógenos utilizados y que no hubieron diferencias significativas en el efecto inhibitorio, así que las dos concentraciones menores fueron seleccionados ( 0.8 y $1.2 \mathrm{mg} / \mathrm{mL}$ ).

Ensayos en filetes de cachama. Recuento de mesófilos (heterotrofos) en placa, psicrotrofos, coliforme totales, coliforme fecales, cantidad de esporas sulfito reductoras y presencia de Salmonella spp., fueron determinados según los estándares de las Normas del Instituto Nacional de Vigilancia de Medicamentos y Alimentos- INVIMA y Normas Técnicas Colombianas (12).

Conteo de mesofilos en placa y psicrotrofos: $11 \mathrm{~g}$ de la muestra se añadieron a $99 \mathrm{ml}$ de agua peptonada $(0.1 \% \mathrm{w} / \mathrm{v})$ y colocados en placas Petri con Agar PlateCount e incubados a $35 \pm 2{ }^{\circ} \mathrm{C}$ por 48 horas. Los psicrotrofilos fueron incubados a $4 \pm 0.5^{\circ} \mathrm{C}$ por $5-7$ días. Los resultados fueron expresados como Log de Unidades Formadoras de Colonia/g, (Log CFU/g). 
were expressed as Log of Colony Forming Units/g, (Log CFU/g).

Determination of Salmonella. Twenty five $\mathrm{g}$ of cachama fillet were homogenized in $225 \mathrm{ml}$ of buffered peptone and incubated at $35 \pm 2^{\circ} \mathrm{C}$ for 18 to 24 hours. $1 \mathrm{ml}$ of the culture was added to one test tube with $10 \mathrm{ml}$ of tetrathionate broth and to another with selenite, to which were added 2 drops of lugol and 2 drops of green coloring at $0.1 \%(\mathrm{w} / \mathrm{v})$. The tubes were incubated at $35 \pm 2{ }^{\circ} \mathrm{C}$ for 18 to 24 hours. The medium of the utilized selective culture was XLD agar and SS agar for the surface exhaustion method and incubation at $35 \pm 2^{\circ} \mathrm{C}$ for 24 hours. The results were reported as positive or negative.

Determination of sulphite reducing spores. $11 \mathrm{~g}$ of the sample were added to $99 \mathrm{ml}$ of universal peptone $(0.1 \mathrm{w} / \mathrm{v})$ and diluted cultures of $1 \mathrm{ml}$, with preliminary thermal shock at $90^{\circ} \mathrm{C}$ for 5 minutes, in petri dishes with SPS agar with the depth method; and incubated at $35 \pm 2{ }^{\circ} \mathrm{C}$ for 72 hours in anaerobiosis. The results were expressed as CFU/g.

\section{Determination of total and fecal coliforms.}

$11 \mathrm{~g}$ of the sample were homogenized in 99 $\mathrm{ml}$ of Fluorocult LMX broth using a vortex and incubation at $35 \pm 2^{\circ} \mathrm{C}$ for 24 to 48 hours. The presence of the gas was determined with a Durham tube and by turbidity of the Brilla broth (Merck). The data were reported as Most Probable Number (MPN).

Sensory analysis. The sensory analysis was done with a descriptive test to judge the quality of the fillets by eight semi-trained panelists. The sensory attributes: appearance, color and aroma were evaluated in fresh fillets. The attributes: taste, texture and appearance were evaluated in cooked fillets. The scoring was based on a scale of four points, with 4 being the best and 1 the worst.

Experimental design and analysis of the data. A factorial design with two factors (time and preservation) was used to study the effect of the preservation treatments with propolis, liquid smoke and time of storage on the quality attributes of the fish fillets. A control and three levels were employed for the preservation treatments. For the factor of time, four storage periods were used $(0,8,16$ and 24 days). Three repetitions were used for each treatment. ANOVA was utilized on the results to evaluate the effect of preservation (A), time (B) and the $A x$ $B$ interaction on the quality attributes, using the software Statgraphics (StatisticalGraphics Corp.
Determinación de Salmonella. Veinte cinco g de filete de cachama se homogenizaron en $225 \mathrm{ml}$ de peptona tamponada e incubados a $35 \pm 2^{\circ} \mathrm{C}$ por 18 a 24 horas. A $1 \mathrm{ml}$ del cultivo se añadió a un tubo de ensayo con $10 \mathrm{ml}$ de caldo de tetrationate y a otro con selenita, a lo cual se añadieron 2 gotas de lugol y 2 gotas de colorante verde a $0.1 \%(\mathrm{w} / \mathrm{v})$. Los tubos se incubaron a $35 \pm 2^{\circ} \mathrm{C}$ por 18 a 24 horas. El medio del cultivo selectivo fue agar XLD y agar SS para el método de agotamiento de superficie e incubado a $35 \pm 2^{\circ} \mathrm{C}$ por 24 horas. Los resultados se reportaron como positivo o negativo.

Determinación de esporas sulfito reductoras. $11 \mathrm{~g}$ de la muestra fueron añadidos a $99 \mathrm{ml}$ de peptona universal $(0.1 \mathrm{w} / \mathrm{v})$ y cultivos diluidos a $1 \mathrm{ml}$, con shock térmico preliminar a $90^{\circ} \mathrm{C}$ por 5 minutos, en placas de Petri con agar SPS con el método de profundidad; e incubados a $35 \pm 2{ }^{\circ} \mathrm{C}$ por 72 horas en anaerobiosis. Los resultados se expresaron en $\mathrm{CFU} / \mathrm{g}$.

Determinación de coliformes totales y fecales. $11 \mathrm{~g}$ de la muestra se homogenizaron en 99 $\mathrm{ml}$ de caldo Fluorocult LMX utilizando un vortex e incubación a $35 \pm 2^{\circ} \mathrm{C}$ por 24 a 48 horas. La presencia del gas se determino con un tubo Durham por turbidez del caldo Brilla (Merck). Los datos se reportaron como Número Más Probable (MPN).

Análisis sensorial. El análisis sensorial se hizo con un ensayo descriptivo para determinar la calidad de los filetes por ocho panelistas semi entrenados. Los atributos sensoriales: apariencia, color y aroma se evaluaron en filetes frescos. Los atributos: gusto, textura, y apariencia se evaluaron en los filetes cocidos. El puntaje se basó en una escala de cuatro puntos, siendo 4 la mejor y 1 la peor.

Diseño experimental y análisis de datos. Un diseño factorial con dos factores (tiempo y conservación) se usaron para estudiar el efecto de los tratamientos de conservación con propóleos, humo líquido y el tiempo de almacenaje sobre los atributos de calidad de los filetes de pescado. Un control y tres niveles fueron usados para los tratamientos de conservación. Para el factor tiempo, cuatro periodos de almacenaje se usaron $(0,8,16$ y 24 días). Cada tratamiento se repitió tres veces. Se utilizó ANOVA en los resultados para evaluar el efecto de conservación (A), tiempo (B) y la interacción $A \times B$ en los atributos de calidad, utilizando software Statgraphics (StatisticalGraphics Corp. Rockville, USA). La diferencia entre el promedio de los valores de los diferentes tratamientos y el periodo de almacenaje fue determinado por la prueba de mínima diferencia significativa (LSD) y la diferencia estadística se definió $\mathrm{p} \leq 0.05$. 
Rockville, USA). The difference between the mean of the values of the different treatments and the storage period was determined by the Least Significant Difference test (LSD) and the statistical difference was defined as $\mathrm{p} \leq 0.05$.

\section{RESULTS}

In vitro microbiological analysis. Table 1 shows the inhibition halos that were obtained using the concentrations of $0.8,1.2$ and $1.6 \mathrm{mg} /$ $\mathrm{ml}$ of EEP. It was observed that, in all cases, the substances inhibited the growth of the bacterial pathogens as compared to the control.

Table 1. Diameter of the halos of inhibition of the in vitro tests for the different concentrations of propolis.

\begin{tabular}{|c|c|c|c|c|}
\hline \multirow[b]{2}{*}{ Bacteria } & \multicolumn{3}{|c|}{$\begin{array}{c}\text { Concentration of ethanol extract } \\
\text { of propolis }\end{array}$} & \multirow{2}{*}{$\begin{array}{l}\text { Control } \\
\text { Ethano } \\
\text { alcohol }\end{array}$} \\
\hline & $0.8 \mathrm{mg} / \mathrm{ml}$ & $\begin{array}{c}1.2 \mathrm{mg} / \\
\mathrm{ml}\end{array}$ & $1.6 \mathrm{mg} / \mathrm{ml}$ & \\
\hline S. aureus & 14 & 16 & 17 & 0 \\
\hline Salmonella & 15 & 16 & 15 & 0 \\
\hline E. coli & 15 & 15 & 17 & 0 \\
\hline Clostridium sp. & 16 & 17 & 18 & 0 \\
\hline
\end{tabular}

Values reported as halo of inhibition in $\mathrm{mm}$.

No significant differences ( $p>0.05)$ were found for the different concentrations $(0.8,1.2$ and $1.6 \mathrm{mg} / \mathrm{mL}$ ) when the diffusion technique was used to test the antagonism between the ethanol extract of propolis and Salmonella, E. coli, S. aureus and Clostridum sp. As a result, only the two lower concentrations were used.

Microbiological analysis of the fillets. Figure 1 show the results for the microbial growth of the mesophile and psychrotrophile microorganisms in the cachama fillets for each treatment during the 24 days of the sampling.

Figure 1 and table 2 show the values of the microbiological counts of the tests carried out on the cachama fillets, in accordance with

Table 2. Microbiological count values for cachama fillets, using ethanol extract of propolis and liquid smoke.

\begin{tabular}{lcccc}
\hline \multicolumn{4}{c}{ Total Coliforms } & \\
& Day 0 & Day 8 & Day 16 & Day 24 \\
\hline EEP 0.8 & $>1100$ & 290 & $>1100$ & $>1100$ \\
EEP 1.2 & $>1100$ & $>1100$ & $>1100$ & $>1100$ \\
Liquid Smoke & $>1100$ & $>1100$ & 240 & $>1100$ \\
Control & $>1100$ & 21 & 460 & $>1100$ \\
Fecal Coliforms & & & & \\
EEP 0.8 & $<3$ & $<3$ & $<3$ & $<3$ \\
EEP 1.2 & 3.6 & $<3$ & $<3$ & 3.6 \\
Liquid Smoke & $<3$ & 7.3 & 6.2 & 9.1 \\
Control & 3.6 & $<3$ & 6.2 & 9.1 \\
\hline
\end{tabular}

\section{RESULTADOS}

Análisis microbiológico in vitro. La tabla 1 muestra los halos de inhibición que se obtuvieron usando las concentraciones de $0.8,1.2$ y 1.6 $\mathrm{mg} / \mathrm{ml}$ de EEP. Se observe que, en todos casos, las sustancias inhibieron el crecimiento de los patógenos bacterianos al ser comparados con el control.

No se encontraron diferencias significativas $(p>0.05)$ para las diferentes concentraciones $(0.8$, 1.2 y $1.6 \mathrm{mg} / \mathrm{mL}$ ) cuando la técnica de difusión se usó para probar el antagonismo entre el extracto de etanol de propóleos y Salmonella, E. coli, S. aureus y Clostridum sp. Como resultado, solo las dos concentraciones menores se usaron.

Análisis microbiológico de los filetes. La figura 1 muestra los resultados del crecimiento microbiano para mesofilos y psicrotrofilos en filetes de cachama para cada tratamiento durante los 24 días del muestreo.

Figura 1 y tabla 2 muestran los valores de los conteos microbioanos de las pruebas llevadas a cabo en los filetes de cachama, según NTC 1325 (13). Los resultados demuestran una carga microbiana inicial representado por mesofilos
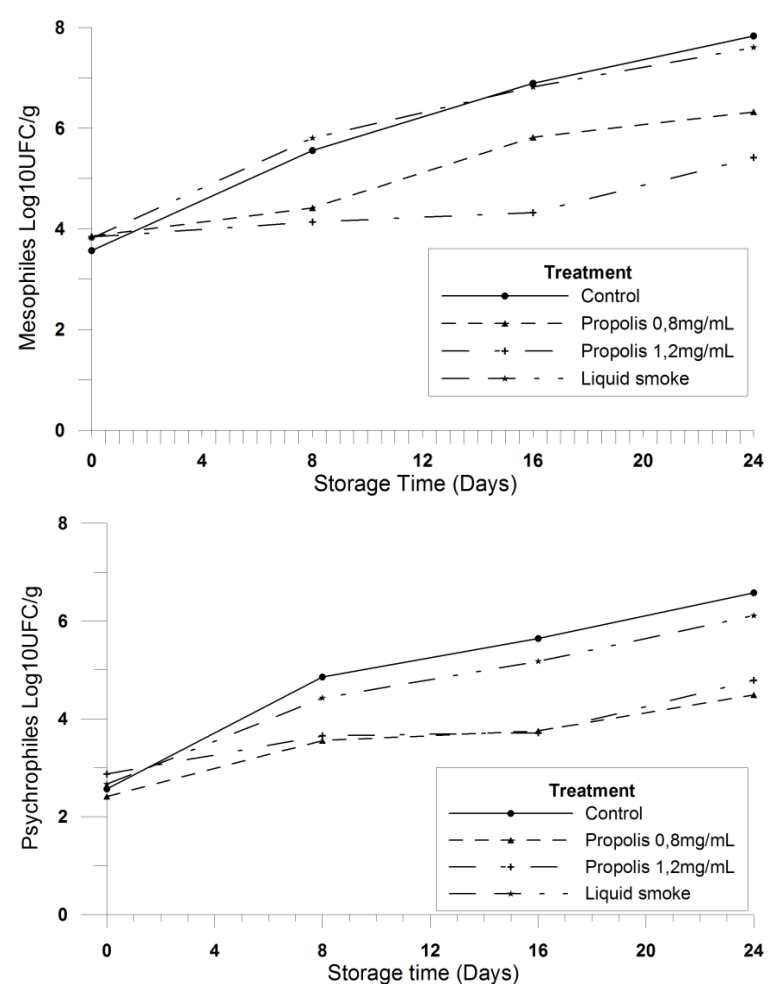

Figure 1. Microbial growth of mesophile and psychrotrophile microorganisms in cachama fillets treated with EEP and liquid smoke. 
NTC 1325 (13). The results demonstrate an initial microbial load represented by aerobic mesophiles and psychrophiles, and total and fecal coliforms, without the presence of Escherichia coli, Salmonella sp., Clostridium sp. or coagulase-positive Staphylococcus.

The mesophile count demonstrated continuous growth over the course of the storage time. The liquid smoke treatment and the control presented counts of $7.4 \mathrm{log}$ CFU/g at 20 days of storage, which is microbiologically unacceptable. While, the propolis treatments still presented acceptable microbiological conditions at this time, with counts of $6.1 \mathrm{log} C F U / g$ and $5.4 \mathrm{log}$ $\mathrm{CFU} / \mathrm{g}$, using EEP concentrations of $0.8 \mathrm{mg} / \mathrm{ml}$ and $1.2 \mathrm{mg} / \mathrm{ml}$, respectively.

The psychrotrophile analysis presented a similar condition, showing continuous growth over the time of storage. The highest counts were seen in the liquid smoke treatment and the control with values of $6.7 \mathrm{log} \mathrm{CFU} / \mathrm{g}$ and $6.1 \mathrm{log} \mathrm{CFU} / \mathrm{g}$, respectively, at the end of the storage period. The EEP treatments presented values of $4.2 \mathrm{log}$ $\mathrm{CFU} / \mathrm{g}$ and $4.5 \log \mathrm{CFU} / \mathrm{g}$ in the concentrations of $0.8 \mathrm{mg} / \mathrm{ml}$ and $1.2 \mathrm{mg} / \mathrm{ml}$, respectively, for the same time period.

The presence of coliforms from the manipulation was reported in the treatments; however, the fecal coliforms presented a lower quantity with values under $3 \mathrm{NMP} / \mathrm{g}$ for the EEP treatments. Values over $3 \mathrm{NMP} / \mathrm{g}$ were seen in the liquid smoke treatment and the control. The aerobic mesophiles presented initial values of $3.8 \mathrm{log}$ $\mathrm{CFU} / \mathrm{g}$ and the psychrophiles had values of 2.4 $\log \mathrm{CFU} / \mathrm{g}$, increasing over the time of storage. There were significant differences $(p<0.05)$ between the EEP treatments and the liquid smoke treatment, as well as the control, with the best microbiological conditions seen in the $1.2 \mathrm{mg} /$ $\mathrm{mL}$ of EEP treatment. The cachama fillets treated with liquid smoke and the control exceeded the acceptable microbiological limits after 20 days of storage.

Sensory analysis. Figures 2 and 3 present the results of the sensory analysis for the cachama fillets treated with EEP for fresh fillet and cooked cachama fillets, respectively. The sensory tests were carried out every 8 days during the 24 days. The panelists graded the sensory attributes of color, aroma, and appearance in fresh cachama fillets and the attributes of taste, texture, and appearance in cooked fillets. In the analysis of the fresh cachama fillets the attribute color scored the highest for the $0.8 \mathrm{mg} / \mathrm{mL}$ EEP treatment. As for aroma, the scores were similar for all the EEP treatments, without significant differences aeróbicos y psicrofilos, y coliformes total y fecal, sin la presencia de Escherichia coli, Salmonella sp., Clostridium sp. o Staphylococcus positivocoagulase.

El conteo de mesófilos demostró crecimiento continuo durante el tiempo de almacenamiento. El tratamiento con humo líquido y el grupo control presentaron cantidades de $7.4 \mathrm{log}$ CFU/g a los 20 días de almacenamiento, el cual es microbiológicamente inaceptable. Los tratamientos de propóleos todavía presentaron condiciones microbiológicas aceptables en este periodo, con conteos de $6.1 \log$ CFU/g y $5.4 \log \mathrm{CFU} / \mathrm{g}$, utilizando concentraciones EEP de $0.8 \mathrm{mg} / \mathrm{ml}$ y $1.2 \mathrm{mg} / \mathrm{ml}$, respectivamente.

El análisis para psicrotrófilos presentó una condición similar, mostrando crecimiento continuo durante el periodo de almacenamiento. Los mayores conteos de presentaron en el tratamiento de humo líquido y el grupo control, con valores de $6.7 \mathrm{log} \mathrm{CFU} / \mathrm{g}$ y $6.1 \log \mathrm{CFU} / \mathrm{g}$, respectivamente, al final del periodo de almacenamiento. Los tratamientos EEP presentaron valores de $4.2 \log \mathrm{CFU} / \mathrm{g}$ y $4.5 \mathrm{log} \mathrm{CFU} / \mathrm{g}$ en concentraciones de $0.8 \mathrm{mg} / \mathrm{ml} \mathrm{y} 1.2 \mathrm{mg} / \mathrm{ml}$, respectivamente, para el mismo periodo de tiempo.

La presencia de coliformes por manipulación fue reportado en los tratamientos; sin embargo, los coliformes fecales presentaron una cantidad menor, con valores por debajo de $3 \mathrm{NMP} / \mathrm{g}$ por los tratamientos EEP. Valores sobre $3 \mathrm{NMP} / \mathrm{g}$ fueron reportados en el tratamiento de humo líquido y el grupo control. Los mesofilos aeróbicos presentaron valores iniciales de $3.8 \log \mathrm{CFU} / \mathrm{g}$ y los psicrofilos tuvieron valores de $2.4 \mathrm{log} \mathrm{CFU} / \mathrm{g}$, aumentando durante el periodo de almacenamiento. Se mostraron diferencias significantes $(p<0.05)$ entre los tratamientos EEP y el tratamiento de humo líquido, además del grupo de control, con las mejores condiciones microbiológicas presente en el $1.2 \mathrm{mg} / \mathrm{mL}$ del tratamiento EEP. Los filetes de cachama tratados con humo líquido y el grupo control excedieron los límites aceptables microbiológicos después de 20 días de almacenamiento.

Análisis sensorial. Figuras 2 y 3 presentan los resultados del análisis sensorial para los filetes de cachama tratados con EEP para filetes de cachama frescos y cocidos, respectivamente. Las pruebas sensoriales se hicieron cada 8 días durante 24 días. Los panelistas tomaron en cuenta los atributos sensoriales de color, aroma, y apariencia de filetes frescos de cachama y los atributos de sabor, textura y apariencia de los filetes cocidos. En el análisis de los filetes frescos de cachama, el atributo de color presento los mejores valores para el tratamiento EEP $0.8 \mathrm{mg} / \mathrm{mL}$. En cuanto a aroma, las calificaciones fueron similares para todos los tratamientos EEP, 
( $p>0.05)$. The appearance was preferred by the panelists in the $1.2 \mathrm{mg} / \mathrm{ml}$ EEP treatment. The lowest values were seen in the liquid smoke treatment and the control, with samples from day 24 being rejected by the panelists in the evaluation of the three attributes.

The results of the sensory evaluation for the cooked cachama fillets that were preserved with EEP are presented in figure 3.

The sensory analysis for the taste attribute in the cachama fillets of the EEP treatments did not present significant differences $(p>0.05)$. The obtained values decreased during the storage period, with values of 2.20 at the end, which were acceptable to the judges. The liquid smoke treatment and the control were rejected by the evaluators at the end of the storage period. The analyses of texture and appearance produced similar results for the EEP treatments, with no significant difference $(p>0.05)$. However, the liquid smoke treatment and the control presented low values starting at day 16 and values that were rejected by the judges on day 24 of the storage.

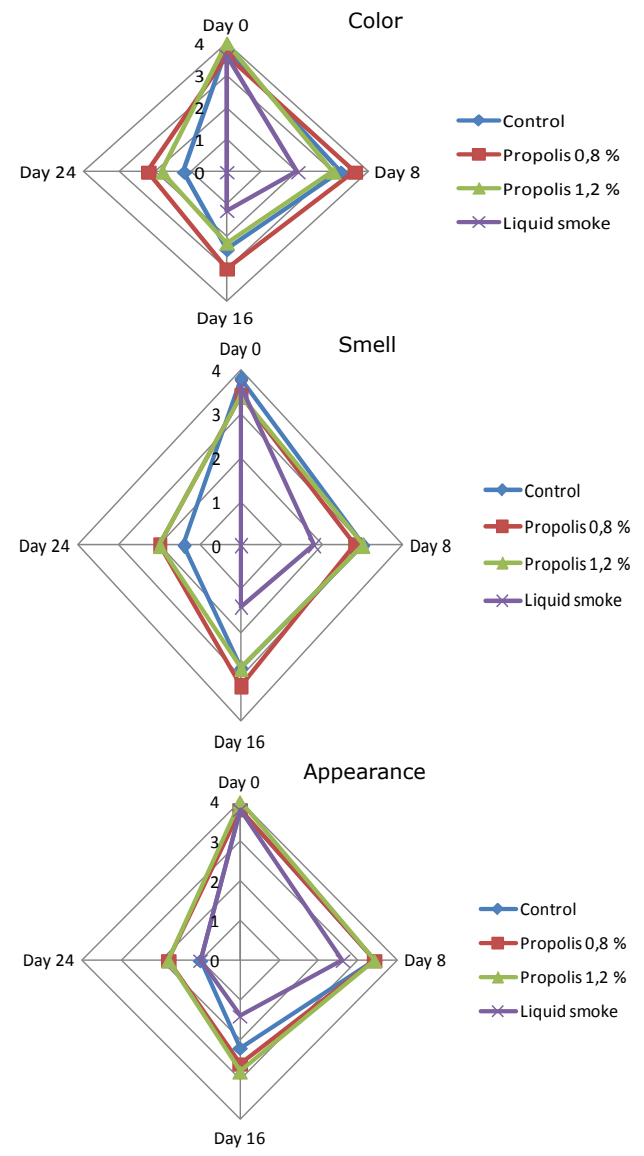

Figure 2. Sensory analysis for the cachama fillets treated with ethanol extract of propolis (EEP) analysis of color, aroma and appearance. sin diferencias significativas ( $p>0.05)$. La apariencia del tratamiento EEP de $1.2 \mathrm{mg} / \mathrm{ml}$ fue preferido por los panelistas. Los valores más bajos se vieron en el tratamiento de humo líquido y el control, con muestras del día 24 siendo rechazadas por los panelistas en la evaluación de los tres atributos.

Los resultados de la evaluación sensorial para los filetes cocidos de cachama que se preservaron con EEP son presentados en figura 3.

El análisis sensorial para el atributo de sabor en los filetes de cachama de los tratamientos EEP no presentaron diferencias significativas $(p>0.05)$. Los valores obtenidos bajaron durante el periodo de almacenamiento, con valores de 2.20 al final, que fueron aceptables a los jueces. El tratamiento con humo líquido y el grupo control fueron rechazados por los evaluadores al final del periodo de almacenamiento. El análisis de textura y apariencia produjeron resultados similares para los tratamientos EEP, sin diferencias significativas ( $p>0.05)$. Sin embargo, el tratamiento de humo líquido y el grupo control presentaron valores bajos iniciando el día 16 y con valores rechazados por los jueces a partir del día 24 del almacenamiento.

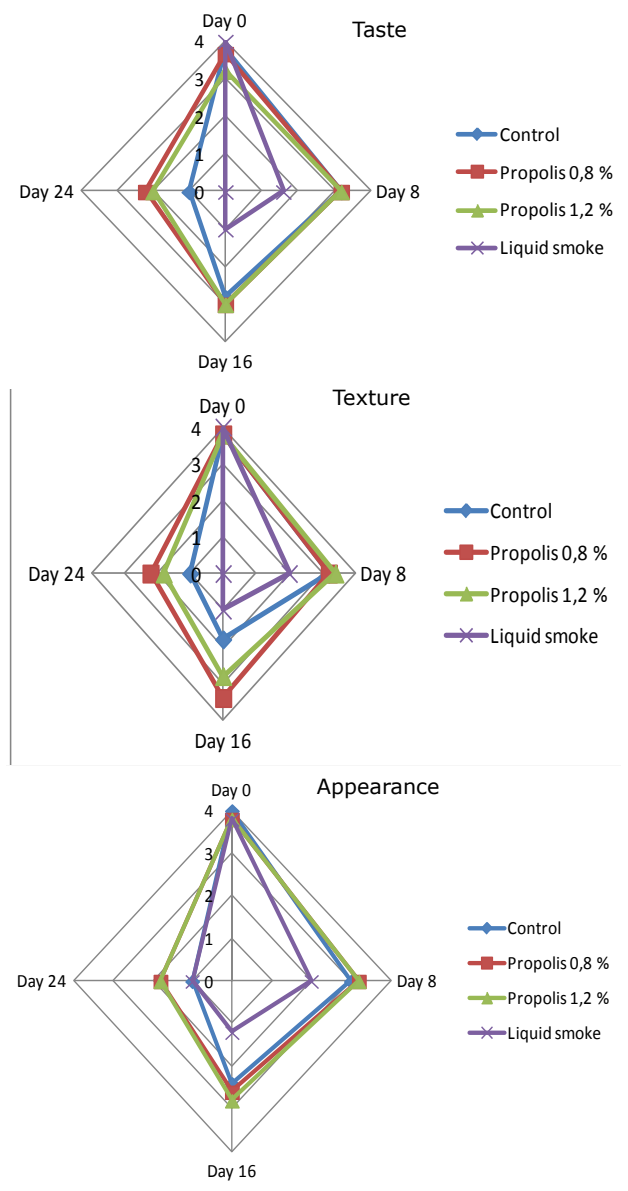

Figure 3. Sensory analysis of taste, texture and appearance for cooked cachama fillets that were preserved with ethanol extract of propolis. 


\section{DISCUSSION}

In vitro microbiological analysis. Inhibition halos were observed with diameters starting at $8 \mathrm{~mm}$ for the evaluated concentrations. The diameter of the halos is considered a inhibition test, in accordance with other authors (14), the diffusion method has been used and the antimicrobial activity of EEP against $S$. aureus has been reported in different regions of Argentine, presenting inhibition halos with diameters starting at $9 \mathrm{~mm}$, which were considered as important antimicrobial activity.

It has been reported that EEP concentrations of $1.25 \mathrm{mg} / \mathrm{ml}$ have inhibition activity against Gram positive bacteria and $5 \mathrm{mg} / \mathrm{ml}$ concentrations have inhibition activity vs. Gram negative bacteria (15), values that surpass those reported in this study.

On the other hand, Palomino et al (16) indicated that bacteria such as E. coli, S. aureus and $S$. tiphi did not present a reduction in growth in the presence of ethanol extracts of propolis, while the Gram positive bacterium $B$. subtilis was sensitive to concentrations of 1.0 and 10.0 $\mathrm{mg} / \mathrm{ml}$, presenting a bacteriostatic effect at $1.0 \mathrm{mg} / \mathrm{ml}$ and a bactericide effect at $10.0 \mathrm{mg} /$ $\mathrm{ml}$, with $8.0 \mathrm{~mm}$ inhibition halos. And so, the higher antimicrobial effect of propolis against Gram positive bacteria and the lower effect against Gram negative bacteria are well known. The results obtained for $E$. coli do not agree with those reported by Brehm-Stecher and Jonson (17), who showed that Gram negative bacteria, such as $E$ coli, possess an additional membrane called the "OM structure" that confers a higher degree of resistance against antimicrobial agents. Equally, Kim and Chung (18) did not report any evidence of inhibition of Salmonella Typhimurium and Escherichia coli when $2.3 \mathrm{mg} / \mathrm{mL}$ of ethanol extract of propolis was used. The results of the present study showed considerable inhibition of Salmonella spp., and E. coli, however some constituents, the application dose, the probable presence of non-volatile compounds (3), of course, the botanic origin may contribute to the variation in the antimicrobial effect of propolis on the microorganisms.

Microbiological analysis of the fillets. According to Bankova (2), a dose of EEP that would be safe for human consumption is 1.4 $\mathrm{mg} / \mathrm{kg}$ of body weight/day, or approximately $70 \mathrm{mg} /$ day in adults. As a reference, benzoic acid and sodium benzoate were used, which are listed as food additives and cataloged as GRAS (generally recognized as safe) by the

\section{DISCUSIÓN}

Análisis microbiológico in vitro. Los halos de inhibición se observaron con diámetros comenzando con $8 \mathrm{~mm}$ para las concentraciones evaluadas. El diámetro de los halos se considera una prueba de inhibición, en conformidad con otros autores (14), el método de difusión se ha usado y la actividad antimicrobiana de EEP contra S. aureus ha sido reportado en diferentes regiones de Argentina, presentando halos de inhibición con diámetros a partir de $9 \mathrm{~mm}$, que se consideraron como señal de actividad antimicrobiana importante.

Se ha reportado que concentraciones EEP de $1.25 \mathrm{mg} / \mathrm{ml}$ tienen actividad de inhibición contra bacterias Gram positivas y concentraciones de $5 \mathrm{mg} / \mathrm{ml}$ provocan inhibición de actividad contra bacterias Gram negativas (15), valores que sobrepasan los reportados en este estudio.

Por otro lado, Palomino et al (16) indicaron que bacterias como E. coli, S. aureus y S. tiphi no presentaron una reducción en crecimiento en la presencia de extractos etanólicos de propóleos, mientras que la bacteria Gram positiva $B$. subtilis se mostró sensible a concentraciones de 1.0 y $10.0 \mathrm{mg} / \mathrm{ml}$, presentando un efecto bacteriostático a los $1.0 \mathrm{mg} / \mathrm{ml}$ y un efecto bactericida a 10.0 $\mathrm{mg} / \mathrm{ml}$, con halos de inhibición de $8.0 \mathrm{~mm}$. Así, el efecto antimicrobiano más alto de propóleos contra bacterias Gram positivas y el menor efecto contra bacterias Gram negativas son bien conocidos. Los resultados obtenidos por $E$. coli no coinciden con los reportados por Brehm-Stecher y Jonson (17) quienes mostraron que bacterias Gram negativas, tal como E. coli, posee una membrana adicional llamado la "estructura OM" que confiere un grado más alto de resistencia contra agentes antimicrobianos. De la misma manera, Kim y Chung (18) no reportaron evidencia de inhibición de Salmonella Typhimurium y Escherichia coli cuando se usó $2.3 \mathrm{mg} / \mathrm{mL}$ de extracto etanólico de propóleos. Los resultados de este estudio mostraron una inhibición considerable de Salmonella spp., y $E$. Coli; sin embargo algunos constituyentes, la dosis de aplicación, la presencia probable de compuestos no volátiles (3) y claro, el origen botánico pueden contribuir a la variación en el efecto antimicrobiano de propóleos en los microorganismos.

Análisis microbiológico de los filetes. Según Bankova (2), una dosis de EEP que sería innocuo para el consumo humano sería de $1.4 \mathrm{mg} / \mathrm{kg}$ de peso corporal/día, o aproximadamente $70 \mathrm{mg} /$ día en adultos. Como referencia, se usaron ácido benzoico y sodio benzoato, que son considerados aditivos alimenticios y catalogados como GRAS (generalmente reconocidos como seguro) por el FDA. La ingesta diaria aceptable (ADI) de las 
FDA. The acceptable daily intake (ADI) of both substances has values between 0 and $5 \mathrm{mg} / \mathrm{kg}$ of body weight. As a result, EEP can successfully inhibit microorganisms such as Salmonella, $E$. coli, S. aureus and Clostridum sp., at levels that are safe for human consumption and, as a consequence, can be used as a biopreservative or a food preservative with an unspecified antibacterial action (9).

Melliou et al (19) reported that EEP from Greece inhibited four different species of Gram negative bacterium (E. coli, E. cloacae, K. pneumoniae, P. aeruginosa). Equally, EEP from Bulgaria inhibited $90.0 \%$ of the tested Gram negative bacteria (20), while Da Silva et al (21) did not find an inhibitory activity in extracts of propolis from Brazil and Bulgaria against a strain of E. coli. Furthermore, extracts of propolis from Brazil and Korea inhibited Gram negative bacteria such as $S$. Typhimurium, but did not inhibit Pseudomonas aeruginosa (22). In general, it is reported that the antimicrobial spectrum is related to the presence of terpenoid compounds. Although more than 300 compounds have been identified in propolis samples, the biological activity must be principally due to some of the scarcer substances, such as flavonoids, terpenes, phenolic acid and their esters, with antimicrobial properties, and to a synergistic combination $(1,2)$. This could offer an explanation for the antimicrobial effectiveness for a microorganism, depending on the origin of the propolis, since the components are determinants for some bacterial strains.

Sensory analysis. The use of EEP as a preservative could influence the sensory attributes, principally affecting taste due to the presence of ethanol compounds, which, in some cases, could negatively affect the final taste of the fish. The results of the present study demonstrate that the presence of ethanol compounds did not negatively affect the perception of the evaluators, which is in agreement with other authors (23). Furthermore, the thermal shock treatment allowed for the removal of intramuscular bones without negatively affecting the sensorial acceptance, which is also in agreement with other authors (24).

In conclusions the EEP used in this study could be effective for the control of Gram positive bacteria and some Gram negative bacteria that are present in cachama fillets; and could be an alternative to the use of chemical preservatives. dos sustancias tiene valores entre 0 y $5 \mathrm{mg} / \mathrm{kg}$ de peso corporal. Como resultado, EEP puede inhibir de manera exitosa los microrganismos como Salmonella, E. coli, S. aureus y Clostridum sp., a niveles que son seguros para el consumo humano y como consecuencia se pueden usar como bioconservante o conservante de alimentos con una acción antibacteriana no especificada (9).

Melliou et al (19) reportaron que EEP de Grecia inhibió cuatro diferentes especias de bacterias Gram negativas (E. coli, E. cloacae, K. pneumoniae, $P$. aeruginosa). De modo similar, EEP de Bulgaria inhibió $90.0 \%$ de bacterias Gram negativas (20), mientras Da Silva et al (21) no encontraron una actividad inhibitoria en extractos de propóleos de Brasil y Bulgaria contra una cepa de E. coli. Además, extractos de propóleos de Brasil y Corea mostraron que bacterias Gram negativas, tales como $S$. Typhimurium, pero no inhibieron Pseudomonas aeruginosa (22). En general, se ha reportado que el espectro antimicrobiano se relaciona a la presencia de compuestos terpenoides. Aunque más de 300 compuestos se han identificado en muestras propóleos, la actividad biológica debe ser debido principalmente a algunas de las sustancias menos comunes, como los flavonoides, terpenos, acido fenólico y sus esteres, con propiedades antimicrobianas, y a una combinación sinérgica $(1,2)$. Esto podría explicar porque existe cierta actividad antimicrobiana por un microorganismo, dependiendo del origen del propóleos, puesto que los componentes son determinantes para algunas cepas de bacteria.

Análisis sensorial. El uso de EEP como preservante podría influir en los atributos sensoriales, principalmente afectando el sabor debido a la presencia de compuestos etanólicos, que en algunos casos podría afectar de manera negativa el sabor final del pescado. Los resultados de este estudio demuestran que la presencia de compuestos etanólicos no afecta de manera negativa la percepción de los evaluadores, coincidiendo con otros autores (23). Además, el tratamiento térmico permitió degradar las espinas intramusculares sin afectar de manera negativa la aceptación sensorial, en concordancia con otros autores (24).

En conclusión, el EEP usado en este estudio podría ser efectivo para controlar bacterias Gram positivas y algunas bacterias Gram negativas que son presentes en los filetes de cachama, y puede ser una alternativa al uso de conservantes químicos. 


\section{REFERENCES}

1. Popova M, P., Bankova V, S., Bogdanov S, Tsvetkova I, Naydenski C, Marcazzan G, Luigi, et al. Chemical characteristics of poplar type propolis of different geographic origin. Apidologie 2007;38(3):306.

2. Bankova V. Recent trends and important developments in propolis research. J Evid Based Complementary Altern Med 2005;2(1):29-32.

3. Castaldo S, Capasso F. Propolis, an old remedy used in modern medicine. Fitoterapia $2002 ; 73: \mathrm{S} 1-\mathrm{S} 6$.

4. Silici S, Kutluca S. Chemical composition and antibacterial activity of propolis collected by three different races of honeybees in the same region. J Ethnopharmacol 2005;99(1):69-73.

5. Drago L, De Vecchi E, Nicola L, Gismondo $M$. In vitro antimicrobial activity of a novel propolis formulation (Actichelated propolis). J Appl Microbiol 2007;103(5):1914-21.

6. Sawaya AC, Souza KS, Marcucci MC, Cunha I, Shimizu MT. Analysis of the composition of Brazilian propolis extracts by chromatography and evaluation of their in vitro activity against gram-positive bacteria. Braz J Microbiol 2004;35(1-2):104-9.

7. Erkmen O, Özcan MM. Antimicrobial effects of Turkish propolis, pollen, and laurel on spoilage and pathogenic foodrelated microorganisms. J Med Food 2008;11(3):587-92.

8. Cho J, Kim Y, Kwon M. Antibacterial effects of propolis extracts on pathogenic bacteria. J East Asian Soc Dietary Life 2005(15:4):57-64.

9. Tosi EA, Ré E, Ortega ME, Cazzoli AF. Food preservative based on propolis: Bacteriostatic activity of propolis polyphenols and flavonoids. Food Chem 2007;104(3):1025-9.

10. Mascheroni E, Guillard V, Nalin F, Mora L, Piergiovanni L. Diffusivity of propolis compounds in Polylactic acid polymer for the development of anti-microbial packaging films. J Food Eng 2010;98(3):294-301.
11. Kalogeropoulos N, Konteles SJ, Troullidou E, Mourtzinos I, Karathanos VT. Chemical composition, antioxidant activity and antimicrobial properties of propolis extracts from Greece and Cyprus. Food Chem $2009 ; 116(2): 452-61$.

12. Certificación ICdNTy. Norma técnica Colombiana NTC 1443. Productos de la pesca y acuicultura. Pescado entero, medallones y trozos, refrigerados o congelados. 2009.

13. Certificación ICdNTy. Norma Técnica CoIombiana. NTC 1325. Industrias alimentarias. Productos cárnicos procesados no enlatados. Icontec Bogotá D.C; 2008.

14. Chaillou LL, Nazareno MA. Bioactivity of propolis from Santiago del Estero, Argentina, related to their chemical composition. Lebenson Wiss Technol. 2009;42(8):1422-7.

15. Mohammadzadeh $S$, Shariatpanahi $M, \mathrm{Ha}-$ medi M, Ahmadkhaniha R, Samadi N, Ostad $\mathrm{SN}$. Chemical composition, oral toxicity and antimicrobial activity of Iranian propolis. Food Chem 2007;103(4):1097-103.

16. Palomino García LR, Martínez Galán JP, García Pajón CM, Gil González JH, Durango Restrepo DL. Caracterización fisicoquímica y actividad antimicrobiana del propóleos en el Municipio de la Unión (Antioquia, Colombia). Rev Fac Nal Agr Medellín 2010; 63(1):5373-83.

17. Brehm-Stecher B, Johnson E. Sensitization of Staphylococcus aureus and Escherichia coli to antibiotics by the sesquiterpenoids nerodiol, farnesol, bisabolol and apritone. Antimicrob Agents Chemother 2003;47(10):3357-60.

18. Kim Y-H, Chung H-J. The effects of Korean propolis against foodborne pathogens and transmission electron microscopic examination. N Biotechnol 2011;28(6):713-8.

19. Melliou E, Stratis E, Chinou I. Volatile constituents of propolis from various regions of Greece-Antimicrobial activity. Food Chem 2007;103(2):375-80. 
20. Boyanova L, Kolarov R, Gergova G, Mitov I. In vitro activity of Bulgarian propolis against 94 clinical isolates of anaerobic bacteria. Anaerobe 2006;12(4):173-7.

21. Da Silva JFM, De Souza MC, Matta SR, De Andrade MR, Vidal FVN. Correlation analysis between phenolic levels of Brazilian propolis extracts and their antimicrobial and antioxidant activities. Food Chemistry 2006; 99(3):431-5.

22. Choi Y, Noh D, Cho S, Suh H, Kim K, Kim J. Antioxidant and antimicrobial activities of propolis from several regions of Korea. Lebenson Wiss Technol 2006;39(7):756-61.
23. Haščík P, Garlík J, Elimam IOE, Kačániová M, Pochop J, Bobko M, et al. Sensory quality of poultry meat after propolis application. J Microbiol Biotechnol Food Sci $2011 ; 2: 172-186$.

24. Suárez Mahecha H, Pardo Carrasco SC, Cortés Rodríguez M. Calidad físico-química y atributos sensoriales de filetes sajados biopreservados de cachama, empacados al vacío bajo refrigeración. Rev Colom Cienc Pecu 2009: 21(3):330-339. 